\title{
Disruption Without Anger: How to Change America Without Being Angry An Interview with Andrew Young
}

Stephen K. Klasko ${ }^{1 *}$ 


\section{ndrew Young, legend and icon of the civil rights movement, came to Philadelphia in February to talk about change, happiness, and health. He sat down with Healthcare Transformation's Editor-in-Chief, Stephen Klasko, for a "fireside chat" at THOMAS JEFFERSON UNIVERSITY.}

Young was the chief deputy to Dr. Martin Luther King, Jr., and executive director of the SoutHERN Christian Leadership Conference. He was elected to Congress, served as the U.S. Ambassador to the United Nations, and became mayor of Atlanta.

He asked Steve to call him "Andy."

Dr. Klasko: Andy, I just have to tell you this talk is a professional and personal highlight of my life. Personal because growing up, my icons were you and Jimi Hendrix-you because I wanted to change the world, and Jimi because I wanted to play guitar.

You've been able to be both a positive disrupter and a unifier at the same time. As we look at this election, everybody's angry. But you are talking about being positively disruptive and changing America without having to be angry.

Mr. Young: Look, I'm here with you at a medical school. And you have to diagnose your patients. And you have to be sensitive to more than the physical aspects of what the ailments are. That's sort of the way I was trained when my daddy used to say all the time, "Don't get mad, get smart."

In diplomacy and in race relations, I never went into a meeting with a point of view. I always tried to understand my opponent's point of view. And I didn't have any problems. Being black is no problem for me. I'm happy. I'm okay. So why is it a problem for you and you have to have "white" water and "colored" water signs? That's your problem. My only problem was that my ancestors had financed those signs. Because that's where they had spent their money. 


\section{Dr. Klasko: And that's where you created a “disruption.”}

Mr. Young: So we said, we're not going to finance our own oppression. If those signs are important to you, keep 'em. And it worked. One hundred businessmen signed a petition to create that change. I came to the conclusion that if 100 businessmen agreed that something is good for the city, if they can come to that agreement, it can change.

It's far more complicated now than it was in the 1950s and 1960s, but we can create change.

Dr. Klasko: You thought the movie Selma was as accurate as a movie could be, maybe except for the scenes with Martin Luther King and Lyndon Johnson?

Mr. Young: They had enormous respect for each other.

\section{6 of all the forms of inequality, injustice in healthcare is the most shocking and inhumane.}

The only thing that was wrong in the movie is it had Martin [Luther King] standing out almost talking loud to Lyndon Johnson. Martin never talked loud to anyone.

Dr. Klasko: I want to shift to today. Martin Luther King is quoted saying "Of all the forms of inequality, injustice in healthcare is the most shocking and inhumane." But now the Affordable Care Act is only approved by a minority of Americans. How do we explain that?

Mr. Young: Harry Truman tried to do something with health insurance in 1948. And I tried to do something when I went into the Congress in 1972. It was the only time I'd ever been booed. I came back and talked to the county medical association. Nobody said anything, and half the group walked out. It was so irrational. This was Georgia in 1973 and had nothing to do with Obama.

I just think it's cheaper to keep people well than to treat them when they get sick.

Dr. Klasko: Amen. Let's applaud that. 
Mr. Young: We're working with the Y [YMCA], and one of the things we want to do with the $Y$ is to get the kids to eat right. We're growing the vegetables right there where they see it. And instead of cooking them up with a ham hock, we're growing spices right there that they can put with the vegetables and make it more flavorful. And we have all kinds of programs for seniors, with people in their 80s and 90s coming in to swim laps.

I grew up in New Orleans, where you grow up on grease.

Dr. Klasko: Well, we're talking in a city where scrapple is considered a vegetable.

Until this year I've been proud to be the president of a university that is the namesake of Thomas Jefferson, but recently some suggest we shouldn't be so proud of Thomas Jefferson based on the lens of certain things Jefferson did. Talk about the push to change some of the icons we used to revere, and should we still revere them?

\section{A Brief Look at the Life and Times of Andrew Young}

- March 12, 1932: Born in New Orleans

-1951: Graduated from HowARD UNIVERSITY in Washington, DC at 19 years of age

-1954: Married Jean Childs

- 1955: Ordained as a minister of the UNITED CHURCH OF CHRIST

- 1957: Met Martin Luther King, Jr.

- 1961: Moved to Atlanta and became one of Dr. King's principal lieutenants

- 1963: Participated in the March on Washington, where Dr. King delivered his "I Have a Dream" speech.

- 1964: Appointed Executive Director of the Southern CHRISTIAN LeADerSHIP ConfERence

-1972-1976: Elected and served as a Congressman in the U.S. House of Representatives

- 1977: Appointed U.S. Ambassador to the UNITED NATIONS

-1979: Received the Presidential Medal of Freedom

- 1981 and 1985: Elected Mayor of Atlanta, Georgia

- 2003: Created the ANDREW Young Foundation to support and promote education, health, leadership, and human rights in the United States, Africa, and the Caribbean.

Source: Andrew Young -Academy of Achievement. (Dec. 16, 2015). Retrieved May 23, 2016 from www.achievement .org/autodoc/page/you0bio-1 
Mr. Young: It's dumb-you can't be polite about it - to try to hold people 300 years ago by standards we have today. We haven't been perfect. Dr.

King used to say that you cannot blame anybody for your segregation. Let's not go way back there. Let's go to Saudi Arabia and Iraq and the Sunnis and Shias. I wish [Jimmy] Carter had been elected for another term because I believe we would have worked out an affirmation action for those. When people tell me they want to blow monuments off Stone Mountain, that sounds to me like the Taliban.

We don't want to blow up the past, we want to learn from it. Let's quit worrying about the sociology, and let's get the economics right.

Dr. Klasko: There's a quote attributed to you: that no black person can learn anything from the "Letter From Birmingham Jail"- that it was a revelation for white people.

Mr. Young: Well, that's true. We knew it. We were living it. But nobody ever put it down in such a way that white people understood it. One of the things that held the movement together was the hopes and dreams of an enslaved people. It's time for us to enter into a new promised land ... We knew about the dream. Everybody grew up on Martin Luther King's dream, but the one thing he said that we should not forget here, it is a dream that is deeply rooted in the American dream.

And then he went on to quote the words of Thomas Jefferson:

"We hold these truths to be self-evident..." And that is a powerful statement.

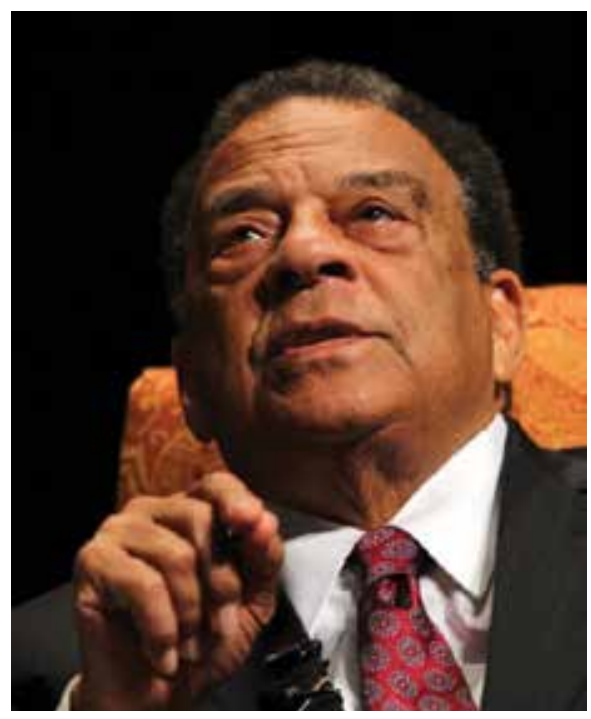

Dr. Klasko: Last night you gave a different view of Dr. King. I asked if you were going to do a biopic, what actor would you have play him? Would you repeat what you said?

Mr. Young: Yeah, I said Eddie Murphy. Because in private, he [Dr. King] was a clown. And he liked to pick on people. He liked to imitate you. He was always imitating other preachers. He made us laugh at our own death. He would say, "Look, you're going to die. Death is the ultimate democracy, 
we're all going to die and nobody has anything to say about when we die and how we're going to die. The only thing you can say something about is what you die for. That's what we're doing here. But if you're hanging out in some club and get shot, it's going to be hard for me to preach you into heaven."

Question from Salaam Peter Beah, medical student at Jefferson: What are the best ways for faith-based organizations to be involved in the wellness of communities?

Mr. Young: All medicine knows the impact of stress. And preachers know how to relieve stress.

I always tell kids that you got to get a song to sing when you're messed up. You talked about Jimi Hendrix, and that generation was messed up, and Jimi Hendrix gave them a song to sing. I've suddenly realized a kind of a chain. Kendrick Lamar and the Black Lives Matter movement have the song, "Alright." And Curtis Mayfield had a song in the sixties, "It's All Right." And the old folks had a song, "I Got a Feeling."

It's the rhythms of the kids. Bob Marley's got a song, "Every Little Thing's Gonna Be All Right."

I'm saying that we got so much to learn, and the church is in the middle of that - that religion and the churches actually provide an emotional release of stress and anxiety.

Dr. Klasko: So here's what we've learned today: stay calm, you can make a difference, laugh a lot, and it's all right.

Mr. Young: It's all right. Have a good time. It's all right. And remember that we founded this country on the words of Thomas Jefferson. AII 